\title{
Vitamin $C$ and total phenols quantification in calli of native passion fruit induced by combinations of Picloram and Kinetin
}

\author{
Quantificação de vitamina C e fenóis totais em calos de maracujazeiro nativo \\ induzidos por combinações de Picloram e Cinetina
}

\author{
Fabiane Aparecida Artioli-Coelho ${ }^{I}$ Renato Paiva ${ }^{\text {II }}$ Luciano Coutinho Silva ${ }^{\text {III }}$ \\ Sandro Barbosa ${ }^{I V}$ Luiz Alberto Beijo ${ }^{\text {IV }}$
}

\section{ABSTRACT}

Brazil is one of the center of origin of passion fruit and has an important natural variability of the genus Passiflora. Several wild species of this genus are resistant to some pests and diseases and many are considered as medicinal. The aim of this research was to induce callus from in vitro Passiflora gibertii leaf explants for quantification of vitamin $C$ and total phenols. Once the appropriate auxin/cytokine balance promotes callus formation and may optimize the production of secondary compounds and vitamins, calli were induced using a half-strength MS medium with a combination of the auxin Picloran (PIC) and the cytokine Kinetin (KIN). The vitamin $C$ and total phenols were quantified by colorimetric methods from calli after different culture periods. The calli induction was strongly dependent of the combination PIC/KIN. It was observed high vitamin C content (94.8mg $\left.100 \mathrm{~g}^{-1}\right)$ during the calli induction period in $M S+4.14 \mu M P I C+0.207 \mu M$ $K I N$. Higher PIC/KIN concentrations promoted an increase in the vitamin $C$ content after three subcultures. The higher PIC $(8.28 \mu M) / K I N(0.828 \mu M)$ concentration was the higher was the total phenols production (66mg tannic acid $100 \mathrm{~g}^{-1}$ of fresh callus) during the calli induction period.

Key words: Passiflora gibertii, native species, medicinal plant, secondary compounds.

RESUMO

O Brasil é um dos centros de origem do maracujazeiro e possui uma importante variabilidade natural do gênero Passiflora. Muitas espécies selvagens desse gênero são resistentes a algumas pragas e doenças e várias são consideradas medicinais. O objetivo deste trabalho foi induzir calos in vitro a partir de folhas de Passiflora gibertii para a quantificação de vitamina $C$ e fenóis totais. Uma vez que o balanço adequado entre auxina/citocinina promove a formação de calos e pode otimizar a produção de compostos secundários e vitaminas, calos foram induzidos em meio MS meia-força com uma combinação da auxina Picloram e da citocinina Cinetina, todos na ausência de luz. O teor de vitamina $C$ e de fenóis totais foi quantificado por métodos colorimétricos após diferentes periodos de cultivo dos calos. A indução de calos foi fortemente influenciada pela combinação de Picloram/Cinetina. Foi observado um alto teor de vitamina $C\left(94,8 m g\left(100 \mathrm{~g}^{-1}\right)\right.$ durante o periodo de indução de

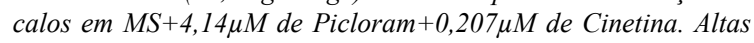
concentrações de Picloram/Cinetina conduzem a um aumento no teor de vitamina $C$ após três subcultivos. Quanto maior a concentração de Picloram $(8,28 \mu \mathrm{M}) /$ Cinetina $(0,828 \mu \mathrm{M})$, maior é a produção de fenóis (66mg de ácido tânico $100 \mathrm{~g}^{-1}$ de calos) totais durante o periodo de indução de calos.

Palavras-chave: Passiflora gibertii, espécie nativa, planta medicinal, compostos secundários.

\section{INTRODUCTION}

Brazil is considered as one of the origin center of passion fruit and is the largest center of geographical distribution of the genus Passiflora (BERNACCI et al., 2003). The country has an important natural variability with the biggest and best Passiflora germplasm collections in the world (ABREU et al., 2009). Moreover, the genus Passiflora is the most cultivated due to its medicinal, ornamental and nutritional characteristics (CERVI et al., 2010). Several wild species of the

'Escola Superior de Agricultura "Luiz de Queiroz", Universidade de São Paulo (USP), Avenida Pádua Dias, 11, 13418-900, Piracicaba, SP, Brasil. E-mail: fabiane_art@yahoo.com.br. Corresponding author.

IDepartamento de Biologia, Setor de Fisiologia Vegetal, Universidade Federal de Lavras (UFLA), Lavras, MG, Brasil.

IIIDepartamento de Biologia Celular e Molecular, Centro de Biotecnologia, Universidade Federal da Paraíba (UFPB), João Pessoa, PB, Brasil.

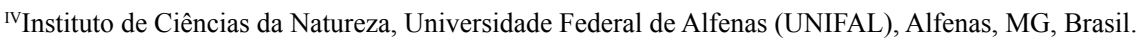


genus Passiflora are resistant to some pests and diseases (JUNQUEIRA et al., 2005) and many have medicinal properties (ABREU et al., 2009) with high concentrations of the chemicals of interest to the pharmaceutical industry (FIGUEIREDO et al., 2007). A third of medicines descended from plants and this fact demonstrates the potential of plants as a source of biologically active and natural products (MILWARD-DE-AZEVEDO, 2008).

The micropropagation is a technique that allows aseptic propagation of plant materials for different purposes(SOUZAetal., 2011; LIMA-BRITO et al., 2011; SANTANA et al., 2010; CAMOLESI et al., 2010; OLIVEIRA et al., 2010). With the progress of biotechnology, the callus culture may be used for the in vitro biosynthesis of compounds of pharmaceutical interest (SANTOS, 2007), therefore reducing the indiscriminate exploitation of medicinal wild species. The production of such compounds is usually stimulated through a stress which can be chemical and/or physical (FUMAGALI et al., 2008). Growth regulators may affect the success of in vitro culture and auxins and cytokinins are widely used. Kinetin is one of the most common cytokinin used to control cell division. Conversely, picloram (2,4-amino-3,5,6trichloropicolinic acid) is a synthetic auxin, generally used at lower concentrations, when compared to other auxins as 2,4-D (2,4-dichlorophenoxyacetic acid) or DICAMBA (3,6-dichloroanisic acid), for instance. Moreover, Picloram and 2,4-D are synthetic auxins commonly used as herbicide, however, Picloram has the less phytotoxic effect (GEORGE et al., 2008). Other factors such as the presence and/or absence of light may also influence the in vitro development (PINHAL et al., 2011).

Studies with the species Passiflora gibertii

N. E. Brown are scarce regarding the quantification of the vitamins and total phenols. Vitamin $\mathrm{C}$ is a natural antioxidant commonly found in the Passiflora genus (SILVA et al., 1999; DE MARCHI et al., 2000; NEPA-UNICAMP, 2011). The passion fruit stands out by their importance in relation to nutritional and antioxidant properties and generally have sedative action (MILWARD-DE-AZEVEDO, 2008). Phenolic compounds are considered secondary metabolites, which can be found in the whole plant (ANGELO \& JORGE, 2007), the nutritional importance of their phenolic compounds in food are well reported by MARTÍNEZ-VALVERDE et al. (2000); ZHENG \& LU, (2011); CASTRO-CONCHA et al. (2014). The synthetic antioxidants may have a carcinogenic potential, thus, the natural ones have become the target of the pharmaceutical industry which aims to product new medicinal substances (YILDRIM et al., 2002). In this context, the aim of this study was to test the interaction of "cytokinin $\times$ auxin" on the induction of callus from in vitro Passiflora gibertii leaf explants and to verify the influence concentrations of PIC and KIN on the parameters calli weight, vitamin $\mathrm{C}$ and total phenols content.

\section{MATERIAL AND METHODS}

Plant material and callus induction

Leaf explants, obtained from in vitro germinated seedlings of native passionflower Passiflora gibertii N. E. Brown - access CPAC MJ22-01 from the germplasm collection of EMBRAPA Cerrado (CPAC) Planaltina - DF were used as explants. In a laminar flow hood, the leaves were excised into $1 \mathrm{~cm} 2$ segments and inoculated into test tubes $(25 \times 150 \mathrm{~mm})$ containing $10 \mathrm{~mL}$ of half-strength MS (MURASHIGE \& SKOOG, 1962) culture medium, which was supplemented with $3 \%$ sucrose. All possible combinations of Kinetin (KIN) (0; 0.207; $0.414 ; 0.621$ and $0.828 \mu \mathrm{M})$ and Picloram (PIC) $(0$; $2.07 ; 4.14 ; 6.21$ and $8.28 \mu \mathrm{M})$, which produced 25 treatments were performed. The $\mathrm{pH}$ was adjusted to $5.8 \pm 0.1$ and the medium was gelled with $0.6 \%$ plant agar before autoclaving at $121^{\circ} \mathrm{C}$ for $20 \mathrm{~min}$. After inoculation, the material was maintained in a growth chamber in the dark at $25 \pm 2^{\circ} \mathrm{C}$ for 60 days, and then, the callus induction as fresh weight $(\mathrm{g})$ was evaluated.

Production of callus for quantification of vitamin C and total phenols

The vitamin $\mathrm{C}$ content and total phenols were determined in calli produced from leaf explants using the same methodology described above. It was used the following $\mathrm{PIC} / \mathrm{KIN}$ concentrations: $4.14 / 0.207 ; 8.28 / 0.414 ; 8.28 / 0.621$ and $8.28 / 0.828 \mu \mathrm{M}$, respectively. The explants were incubated in a growth chamber in the dark at $25 \pm$ $2{ }^{\circ} \mathrm{C}$ for four cycles of 60 days each (calli induction and subcultures 1, 2 and 3). At the end of each cultivation period, approximately $5 \mathrm{~g}$ of callus for each subculture/treatment were collected for vitamin $\mathrm{C}$ and total phenolic compounds quantification. As a secondary control for vitamin $\mathrm{C}$ quantification, it was also collected $5 \mathrm{~g}$ of leaves from a six-month old plant maintained ex vitro. The leaves were collected in the summer, during the plant active growth.

The vitamin $\mathrm{C}$ content was determined by the colorimetric method using 2,4-dinitrophenylhydrazine according to STROHECKER \& HENNING (1967). The total 
phenols content was determined by the Folin-Denis reagent method, according to AOAC (1990). The results were expressed in $\mathrm{mg}$ of vitamin $\mathrm{C}$ per $100 \mathrm{~g}$ of fresh callus or in $\mathrm{mg}$ of total phenols tannic acid equivalents (TAE) per $100 \mathrm{~g}$ of fresh callus.

\section{Statistical analysis}

The completely randomized experimental design for all experiments was used. The callus induction experiment consisted of 10 replicates per treatment with five tubes per replicate. The results were subjected to ANOVA and the means of the interaction PIC $\times$ KIN regarding the fresh weight of calli $(\mathrm{g})$ were subjected to regression analysis. For the quantification of vitamin $\mathrm{C}$ and total phenols in callus, the interaction, $(\mathrm{PIC} \times \mathrm{KIN}) \times$ culture period, was tested and the treatment means were compared by Scott-Knott test $(\mathrm{P} \leq 0.05)$ All statistical analyses were performed using the statistical software Sisvar ${ }^{\circledR}$ (FERREIRA, 2011).

\section{RESULTS AND DISCUSSION}

Calli induction

It was found that the callus induction in $\boldsymbol{P}$. gibertii from leaf explants was statistically significant $(p<0.001)$ and strongly dependent of the combination of PIC/KIN, which proves the necessity of an optimal auxin/cytokine balance to induce a specific response. Growth regulators free medium showed no calli formation. Trends of callus growth $(\mathrm{g})$ as a function of the interaction PIC $\times$ KIN are shown on figure 1 .

The combination auxin/cytokine is reported by several authors as essential for callus formation. STELLA \& BRAGA (2002) proved that the absence of combination of auxin/cytokine was unable to induce callus in leaf explants of Rudgea jasminoides. ANTOGNONI et al. (2007) report the success of 2,4-D (2,4-dichlorophenoxyacetic acid) and KIN for callus induction on different species of genus Passiflora. PINTO et al. (2011) also report success in obtaining embryogenic callus of $\boldsymbol{P}$. edulis with a combination of 2,4-D and BAP (6-benzylaminopurine). KAUR \& KOTHARI (2004) studied the effect of PIC/KIN in the callus induction on kodo millet (Paspalum scrobiculatum L.) and reported the increase in calli fresh weight was directly proportional with the PIC concentration in the culture medium.

In this research, it was observed that the following combinations of PIC $(\mu \mathrm{M}) \times \operatorname{KIN}(\mu \mathrm{M})$ : 4.14/0.207 (Figure 1B); 8.28/0.414 (Figure 1C); $8.28 / 0.621$ (Figure 1D), and 8.28/0.828, respectively, provided higher values of calli fresh weight $(1.8 ; 1.6$; 1.7 and $1.5 \mathrm{~g}$ ), respectively, at the end of the callus induction period. In the absence of KIN, the higher fresh weight $(0.2 \mathrm{~g})$ was only obtained in the presence of $8.28 \mu \mathrm{M}$ PIC (Figure 1A). No combination PIC $\times$ KIN showed callus formation less than $0.6 \mathrm{~g}$ fresh weight (Figure 1B, C, D and E).

\section{Vitamin C content}

The interaction, $(\mathrm{PIC} \times \mathrm{KIN}) \times$ culture period, was significant $(\mathrm{p}<0.001)$ regarding the vitamin $\mathrm{C}$ production in calli. Highest vitamin $\mathrm{C}$

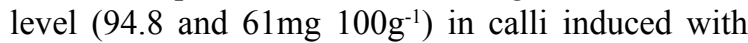
$4.14 \mu \mathrm{M}$ PIC $+0.207 \mu \mathrm{M}$ KIN was obtained, followed by $8.28 \mu \mathrm{M} \mathrm{PIC}+4.14 \mu \mathrm{M} \mathrm{KIN}$, both during the induction period, respectively. However, a reduction in the vitamin $\mathrm{C}$ content following subcultures for these two treatments was observed (Table 1). Moreover, for the treatments $8.28 \mu \mathrm{M}$ PIC $/ 0.621 \mu \mathrm{M}$ $\mathrm{KIN}$ and $8.28 \mu \mathrm{M} \mathrm{PIC} / 0.828 \mu \mathrm{M} \mathrm{KIN}$, the production of vitamin $\mathrm{C}$ has been increased during subculture after the period of callus induction (Table 1). In this study a higher vitamin $\mathrm{C}$ content in calli of $\boldsymbol{P}$. gibertii (94.8mg $\left.100 \mathrm{~g}^{-1}\right)$ was found when compared to the levels found in fruits of $\boldsymbol{P}$ alata $\left(10.26 \mathrm{mg}^{100 \mathrm{~g}^{-1}}\right.$ ) by SILVA et al. (1999). Moreover, high vitamin C content $\left(127.5 \mathrm{mg} 100 \mathrm{~g}^{-1}\right)$ in leaves of $\boldsymbol{P}$. gibertii ex vitro cultivated was also observed. Furthermore, according to the Brazilian table of food composition provided by the Center for Studies and Research on Food (NEPA-UNICAMP, 2011), the commercial species of passionflower P. edulis f. flavicarpa features 19.8, 7.3 and $13.7 \mathrm{mg}$ vitamin $\mathrm{C} / 100 \mathrm{~g}$ in fresh fruit, frozen pulp and concentrated juice, respectively. This value is considerably lower when compared to the level observed on leaves and calli of $\boldsymbol{P}$. gibertii reported in this paper (Table 1). There are rare reports on the literature concerning the levels of vitamin $\mathrm{C}$ in callus of passion fruit.

Total phenols content

Although the interaction, $(\mathrm{PIC} \times \mathrm{KIN}) \times$ culture period, was significant $(p<0.001)$, the total phenols content found in calli was considered lower (Table 1). Even on the leaves of $\boldsymbol{P}$. gibertii ex vitro cultivated the total phenols content was only about $0.7 \% \quad\left(708.6 \mathrm{mg}\right.$ tannic acid $\left.100 \mathrm{~g}^{-1}\right)$. Compared with total phenols present in other plant species, $\boldsymbol{P}$. gibertii did not stand out as a good producer of this metabolite. CARVALHO et al. (2001) quantified the total phenols in the leaves of coffee trees and observed a maximum of $12.7 \%$. CASTRO et al. (2009) working with Stryphnodendron adstringens 


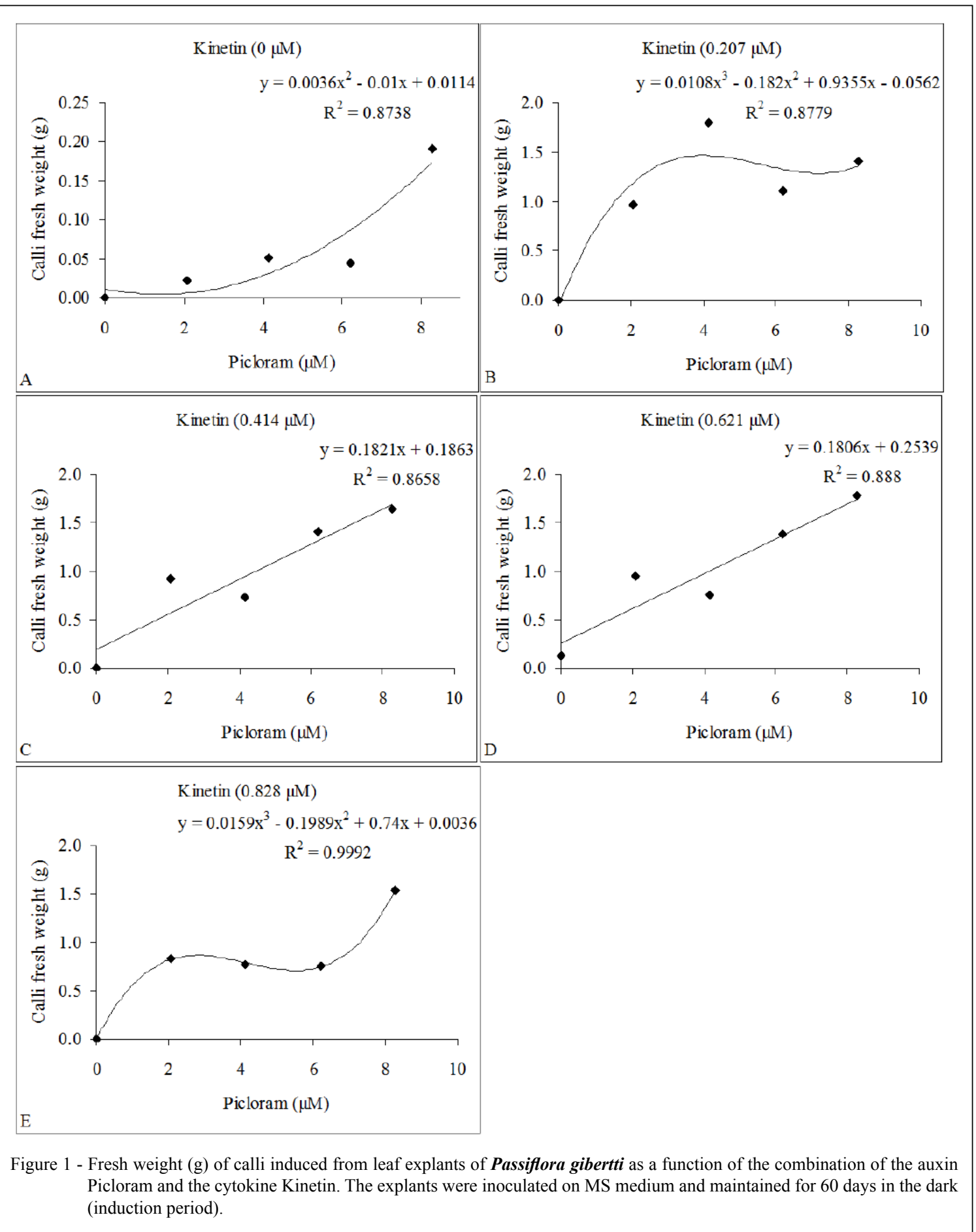

report $1 \%$ or $1.3 \%$ of total phenols content in callus induced on medium containing only $2,4-\mathrm{D}$ or combined with BAP, respectively. The highest total phenols content obtained on $\boldsymbol{P}$. gibertii calli was $0.06 \%$ (66.21 mg tannic acid $100 \mathrm{~g}^{-1}$ ) during the induction period (Table 1). Nevertheless, this content is lower than that found by MALACRIDA \& JORGE (2012) in seed oil of $\boldsymbol{P}$ edulis $(1,314.13 \mathrm{mg}$ GAE/ $\mathrm{kg})$. A reduction in the total phenols at the end of the first subculture was observed (Table1). Likely, it happened due to the removal of the initial explant (leaf segment). During the calli induction phase, cells start to grow over 
Table 1 - Comparisons of the vitamin $\mathrm{C}$ and total phenols content in callus of Passiflora gibertii cultivated on MS medium at different culture periods, in the dark, and at different combinations of the auxin Picloram (PIC) and the cytokine Kinetin (KIN). Assessments were performed at the end of each culture period.

\begin{tabular}{|c|c|c|c|c|}
\hline \multirow{2}{*}{$\begin{array}{l}\mathrm{PIC} / \mathrm{KIN} \\
\mu \mathrm{M}\end{array}$} & \multicolumn{4}{|c|}{--Vitamin $C$ content $\left(\mathrm{mg} 100 \mathrm{~g}^{-1}\right)$} \\
\hline & Induction & $1^{\text {st }}$ subculture & $2^{\text {nd }}$ subculture & $3^{\text {rd }}$ subculture \\
\hline $4.14 / 0.207$ & $94.8 \pm 2.7 \mathrm{aA}$ & $6.9 \pm 0.5 \mathrm{bC}$ & $3.8 \pm 0.7 \mathrm{bD}$ & $14.8 \pm 1.1 \mathrm{bB}$ \\
\hline $8.28 / 0.414$ & $61.3 \pm 0.5 \mathrm{bA}$ & $10.1 \pm 0.7 \mathrm{aB}$ & $4.9 \pm 1.3 \mathrm{bC}$ & $11.2 \pm 0.7 \mathrm{cB}$ \\
\hline $8.28 / 0.621$ & $5.6 \pm 0.2 \mathrm{cB}$ & $8.1 \pm 0.2 \mathrm{aA}$ & $8.6 \pm 0.6 \mathrm{aA}$ & $10.3 \pm 0.5 \mathrm{cA}$ \\
\hline $8.28 / 0.828$ & $3.7 \pm 0.8 \mathrm{dC}$ & $9.5 \pm 0.4 \mathrm{aB}$ & $4.7 \pm 0.2 \mathrm{bC}$ & $22.9 \pm 0.9 \mathrm{aA}$ \\
\hline \multicolumn{5}{|l|}{ PIC/KIN } \\
\hline$\mu \mathrm{M}$ & Induction & $1^{\text {st }}$ subculture & $2^{\text {nd }}$ subculture & $3^{\text {rd }}$ subculture \\
\hline $4.14 / 0.207$ & $16.3 \pm 0.4 \mathrm{~dB}$ & $21.1 \pm 0.3 \mathrm{aA}$ & $20.8 \pm 0.3 \mathrm{aA}$ & $16.9 \pm 0.3 \mathrm{cB}$ \\
\hline $8.28 / 0.414$ & $27.0 \pm 1.4 \mathrm{cA}$ & $0 \pm 0 \mathrm{bD}$ & $6.2 \pm 0.4 \mathrm{bC}$ & $18.4 \pm 1.0 \mathrm{cB}$ \\
\hline $8.28 / 0.621$ & $30.7 \pm 1.4 \mathrm{bA}$ & $0 \pm 0 \mathrm{bD}$ & $5.6 \pm 0.8 \mathrm{bC}$ & $21.1 \pm 1.1 \mathrm{bB}$ \\
\hline $8.28 / 0.828$ & $66.2 \pm 1.7 \mathrm{aA}$ & $0 \pm 0 \mathrm{bD}$ & $6.5 \pm 0.1 \mathrm{bC}$ & $29.2 \pm 0.4 \mathrm{aB}$ \\
\hline
\end{tabular}

Means \pm SD for vitamin $\mathrm{C}$ or total phenols content for each cultivation period followed by the same lowercase letter (columns) or capital letters (rows) do not differ by Scott-Knott test $(\mathrm{P}=0.05)$.

the tissue (GEORGE et al., 2008). To start the first subculture, only the new cells formed, over the initial explant were removed and transferred to a fresh medium. Once leaves contain phenolic compounds (TAIZ \& ZEIGER, 2013), the absence of this tissue on the first subculture may have contributed to not detect this compound at this analysis. During successive subcultures (second and third), portions of the previously calli always are transferred together to the fresh media. It can be explain why the phenols increased following subcultures.

The in vitro environment, in particular the use of high concentrations of growth regulators may contribute to the oxidative stress, resulting in increased production of reactive oxygen species (ROS) (PINTO et al., 2010). The production of vitamin $\mathrm{C}$ and phenolic compounds has a link to the control of this type of stress, since they act as nonenzymatic antioxidants. Thus, the in vitro production of vitamin $\mathrm{C}$ and phenolic compounds could have been a possible response to the oxidative stress caused by the growth regulators PIC and KIN. In this sense, PIC KIN acted as inducers of in vitro oxidative stress, triggering the activation of the pathway of nonenzymatic antioxidants, represented in this research by vitamin $\mathrm{C}$ and phenolic compounds. Enabling this plant defense system against the in vitro oxidative stress through analysis of the activity of antioxidant enzymes is proven in some studies (CARVALHO et al., 2009; MISRA et al., 2010; LUO et al., 2010).

The in vitro production of secondary compounds may facilitate purification of the extracts by the fact that the amount of pigments is insignificant, thus, reducing the costs of production; moreover, the explants are in aseptic condition. According to FUMAGALI et al. (2008), the production of large amounts of secondary metabolites by plant cell culture may occur within a few weeks, unlike the extraction of secondary metabolites of an annual or a perennial plant, which requires a longer time for accumulation of such metabolites.

\section{CONCLUSION}

The vitamin $\mathrm{C}$ content found in calli is high during the calli induction period when low concentrations of Picloram/Kinetin are used. When these regulators are in high concentration, the highest vitamin $\mathrm{C}$ content is obtained after the calli induction period. High Picloram/Kinetin concentration promotes the high total phenols content during calli induction period or during the third subculture. The highest calli induction from Passiflora gibertii leaves are obtained in culture media containing high concentrations of Picloram in the presence of Kinetin.

\section{ACKNOWLEDGEMENTS}

The authors wish to thank Coordenação de Aperfeiçoamento de Pessoal de Nível Superior (CAPES), Conselho Nacional de Desenvolvimento Científico e Tecnológico (CNPq), Fundação de Amparo à Pesquisa do estado de Minas Gerais (FAPEMIG) and the Empresa Brasileira de Pesquisa Agropecuária (EMBRAPA) Cerrados Planaltina-DF researcher, Dr. Nilton Junqueira. 


\section{REFERENCES}

ABREU, P.P. et al. Passion flower hybrids and their use in the ornamental plant market: perspectives for sustainable development with emphasis on Brazil. Euphytica, v.166, n.3, p.307-315, 2009. Available from: <http://www.springerlink.com/content/ d30828p3t51816j3/>. Accessed: Oct. 02, 2012. doi: 10.1007/ s10681-008-9835-x.

ANGELO, P.M.; JORGE, N. Phenolic compounds in foods - a brief review. Revista Instituto Adolfo Lutz, v.66, n. 1, p.232-240, 2007. Available from: <http://periodicos.ses.sp.bvs.br/pdf/rial/ v66n1/v66n1a01.pdf>. Accessed: Oct. 02, 2012.

ANTOGNONI, F. et al. Induction of flavonoid production by UV-B radiation in Passiflora quadrangularis callus cultures. Fitoterapia, v.78, n.5, p.345-352, 2007. Available from: <http://www.sciencedirect.com/science/article/pii/ S0367326X07000986>. Accessed: Oct. 02, 2012. doi: 10.1016/j. fitote.2007.02.001.

ASSOCIATION OF OFFICIAL ANALYTICAL CHEMISTS (AOAC). Official methods of analysis. Arlington Virginia, 1990. 1v, 1298p.

BERNACCI, L.C. et al. Passifloraceae. In (Eds.). Flora fanerogâmica do Estado de São Paulo 3. São Paulo: RiMa/ FAPESP, 2003. p.247-274.

BLOKHINA, O. et al. Antioxidants, oxidative damage and oxygen deprivation stress: a review. Annals of Botany, v.91, n.1, p.179-194, 2003. Available from: <http://aob.oxfordjournals.org/ content/91/2/179.full.pdf + html $>$. Accessed: Sept. 01, 2014. doi: 10.1093/aob/mcf118.

CAMOLESI, M.R. et al. In vitro rooting of micropropagated banana tree (Musa sp.) seedlings in different culture media. Ciência \& Agrotecnologia, v.34, n.6, p.1446-1451, 2010. Available from: <http://www.scielo.br/pdf/cagro/v34n6/13. pdf>. Accessed: Oct. 02, 2012. doi: 10.1590/S141370542010000600013

CARVALHO, J.M.F.C. et al. Mecanismos antioxidantes associados à embriogênese somática. Campina Grande: Embrapa Algodão, 2009. 25p. (Boletim Técnico, 223).

CARVALHO, V.L. et al. Influence of different yield levels on coffee rust evolution and on phenolic compounds on leaves. Ciência Agrotecnologia, v.25, n.1, p.49-54, 2001. Available from: $<$ http://www.editora.ufla.br/_adm/upload/revista/25-1-2001_06. pdf $>$. Accessed: Oct. 02, $201 \overline{2}$.

CASTRO, A.H.F. et al. Callogenesis and contents of total phenols and tannins in barbatimão [Stryphnodendron adsrtingens (Mart.) Coville]. Ciência e Agrotecnologia, v.33, n.2, p.385-390, 2009. Available from: <http://www.scielo.br/pdf/cagro/v33n2/ v33n2a04.pdf $>$. Accessed: Oct. 02, 2012. doi: 10.1590/S141370542009000200004 .

CASTRO-CONCHA, L.A. et al. Antioxidant capacity and total phenolic content in fruit tissues from accessions of Capsicum chinense Jacq. (Habanero Pepper) at different stages of ripening. Scientific World Journal, v.2014, Article ID 809075, p.1-5, 2014. Available from: <http://www.hindawi. com/journals/tswj/2014/809073/>. Accessed: Aug. 21, 2014. doi: $10.1155 / 2014 / 809073$.
CERVI, A.C. et al. Passifloraceae. In: (Eds.). Catálogo de plantas e fungos do Brasil. Rio de Janeiro: Jardim Botânico do Rio de Janeiro, 2010. p.1432-1436.

DE MARCHI, R. et al. Uso da cor da casca como indicador de qualidade do maracujá amarelo (Passiflora edulis Sims. f. flavicarpa Deg.) destinado à industrialização. Ciência e Tecnologia de Alimentos (Impresso), v.20, n3, p.381-387, 2000. Available from: $<$ http://www.scielo.br/scielo.php?pid=S010120612000000300017\&script $=$ sci_arttext $>$. Accessed: Aug. 21, 2014. doi: 10.1590/S0101-20612000000300017.

FERREIRA, D.F. Sisvar: a computer statistical analysis system. Ciência e Agrotecnologia. v.35, n.6, p.1039-1042, 2011. Available from: < http://www.scielo.br/pdf/cagro/v35n6/ a01v35n6.pdf $>$. Accessed: Oct. 02, 2012. doi:10.1590/S141370542011000600001 .

FIGUEIREDO, M.A. et al. Indução in vitro de calos em duas espécies de maracujazeiro nativo. Revista Brasileira de Biociências, v.5, n.2, p.288-290, 2007. Available from: <http:// www6.ufrgs.br/seerbio/ojs/index.php/rbb/article/view/276/243>. Accessed: Oct. 02, 2012.

FUMAGALI, E. et al. Production of plant secondary metabolites in plant cell and tissue culture: the example of Tabernaemontana and Aspidosperma genera. Revista Brasileira de Farmacologia, v.18, n.4, p.627-641, 2008. Available from: <http://www.scielo. br/pdf/rbfar/v18n4/v18n4a22.pdf $>$. Accessed: Oct. 02, 2012. doi: 10.1590/S0102-695X2008000400022.

GEORGE, E.F. et al. Plant propagation by tissue culture. 3.ed. Dordrecht: The Background, 2008. 1v. 501p.

JUNQUEIRA, N.T.V. et al. Potencial de espécies silvestres de maracujazeiro como fonte de resistência a doenças. In: Maracujá: germoplasma e melhoramento genético. Planaltina: Embrapa Cerrados, 2005. p.81-107.

KAUR, P.; KOTHARI, S.L. In vitro culture of kodo millet: influence of 2,4-D and picloram in combination with kinetin on callus initiation and regeneration. Plant Cell, Tissue and Organ Culture, v.77, n.1, p.73-79, 2004. Available from: <http://www. springerlink.com/content/1477858353665858/>. Accessed: Oct. 02, 2012. doi: 10.1023/B:TICU.0000016505.20448.44

LIMA-BRITO, A. et al. In vitro morphogenesis of Syngonanthus mucugensis Giul. subsp. mucugensis. Ciência \& Agrotecnologia, v.35, n.3, p.502-510, 2011. Available from: $<$ http://www.scielo.br/ pdf/cagro/v35n3/10.pdf $>$. Accessed: Oct. 02, 2012. doi: 10.1590/ S1413-70542011000300010.

LUO, Z.B. et al. Effects of zinc on growth and antioxidant responses in Jatropha curcas seedlings. International Journal of Agriculture \& Biology, v.12, p.119-124, 2010. Available from: $<$ http://www.fspublishers.org/published_papers/14062_..pdf > Accessed: Sept. 15, 2014.

MALACRIDA, C.R.; JORGE, N. Yellow passion fruit seed oil (Passiflora edulis f. flavicarpa): physical and chemical characteristics. Brazilian Archives of Biology and Technology, v.55, p.127-134, 2012. Available from: <http://www.scielo.br/pdf/ babt/v55n1/v55n1a16.pdf>. Accessed: Oct. 02, 2012.

MARTÍNEZ-VALVERDE, I. et al. Nutritional importance of phenolic compounds in the diet. Archivos Latinoamericanos de 
Nutrición, v.50, n.1, p.5-18, 2000. Available from: <http://www. ncbi.nlm.nih.gov/pubmed/11048566>. Accessed: Aug. 21, 2014.

MILWARD-DE-AZEVEDO, M.A. Analysis of the valuation of the environment impact and the demand of phytotherapics coming from passion fruit in Brazil. Revista FAE, v.11, n.1, p.19-32, 2008. Available from: $<$ http://www.unifae.br/publicacoes/pdf/revista_da fae/fae_v11_n1/03_michaele.pdf>. Accessed: Oct. 02, 2012.

MISRA, P. et al. Effect of antioxidants and associate changes in antioxidant enzymes in controlling browning and necrosis of proliferating shoots of elite Jatropha curcas L. Biomass and Bioenergy, v.34, p.1861-1869, 2010. Available from: <http:// www.sciencedirect.com/science/article/pii/S0961953410002515>. Accessed: Feb. 02, 2015. doi: 10.1016/j.biombioe.2010.07.027.

MURASHIGE, T.; SKOOG, F. A revised medium for rapid growth and bio assays with tobacco tissue cultures. Physiologia Plantarum, v.15, n.3, p.473-497, 1962. Available from: <http:// onlinelibrary.wiley.com/doi/10.1111/j.1399-3054.1962.tb08052.x/ pdf>. Accessed: Oct. 02, 2012. doi: 10.1111/j.1399-3054.1962. tb08052.x.

NEPA-UNICAMP, "TACO (Brazilian Food Composition Table)," Coordinated by the Center for Studies and Researches in Food (NEPA) of UNICAMP and Established by Ministry of Health (MS). Campinas, 2011. 161p. Available from: <http:// www.unicamp.br/nepa/taco/contar/taco_4_edicao_ampliada_e_ revisada $>$. Accessed: Aug. 21, 2014

OLIVEIRA, L.M. et al. Effects of cytokinins on in vitro mineral accumulation and bud development in Annona glabra L. Ciência \& Agrotecnologia, v.34, n.6, p.1439-1445, 2010. Available from: $<$ http://www.scielo.br/pdf/cagro/v34n6/12.pdf $>$. Accessed: Oct. 02, 2012. doi: 10.1590/S1413-70542010000600012.

PINHAL, H.F. et al. Applications of tissue culture techniques in Brazilian Cerrado fruit trees. Ciência Rural, v.41, n.7, p.11361142, 2011. Available from: <http://www.scielo.br/pdf/cr/v41n7/ a3911cr4848.pdf $>$. Accessed: Oct. 02, 2012. doi:10.1590/S010384782011005000089 .

PINTO, D.L.P. et al. Somatic embryogenesis from mature zygotic embryos of commercial passionfruit (Passiflora edulis Sims) genotypes. Plant Cell Tissue and Organ Culture, v.107, n.3, p.521-530, 2011. Available from: <http:/www.springerlink.com/ content/9134123g45k55158/>. Accessed: Oct. 02, 2012. doi: 10.1007/s11240-011-0003-y.
PINTO, K.S. et al. Avaliação do estresse in vitro em cana-de-açúcar: variedade rb867515. In: Jornada de Ensino, Pesquisa e Extensão. Recife: Editora Universitária, 2010. p.12-15.

SANTANA, J.R.F. et al. Effect of different carbon sources on the in vitro multiplication of Annona sp. Ciência \& Agrotecnologia, v.35, n.3, p.487-493, 2011. Available from: $<$ http://www.scielo. br/pdf/cagro/v35n3/aop0211.pdf $>$. Accessed: Oct. 02, 2012. doi: 10.1590/S1413-70542011005000002.

SANTOS, A.S. Adehydrorotenoid produced by callus tissue culture and wild plant roots of Boerhaavia coccinea. Revista Brasileira de Farmacognosia, v.17, n.4, p.538-541, 2007. Available from: $<$ http://www.scielo.br/pdf/rbfar/v17n4/a11v17n4.pdf $>$. Accessed: Oct. 02, 2012. doi:10.1590/S0102-695X2007000400011.

SILVA, A.P. et al. Plant growth regulators in the postharvest conservation of sweet passion fruit (Passiflora alata Dryander) stored under refrigeration. Ciência e Agrotecnologia, v.23, n.3, p.643-649, 1999. Available from: <http://www.editora.ufla.br/ $\mathrm{adm} /$ upload/revista/23-3-1999_19.pdf $>$. Accessed: Oct. 02, 2012.

SOUZA, A.V. et al. Micropropagation of Dioscorea multiflora Grised. Ciência \& Agrotecnologia, v.35, n.1, p.92-98, 2011 Available from: $\quad<$ http://www.scielo.br/pdf/cagro/v35n1/ a11v35n1.pdf>. Accessed: Oct. 02, 2012. doi: 10.1590/S141370542011000100011

STELLA, A.; BRAGA, M.R. Callus and cell suspension cultures of Rudgea jasminoides, a tropical woody Rubiaceae. Plant Cell, Tissue and Organ Culture, v.68, n.3, p.271276, 2002. Available from: <http://www.springerlink.com/ content/u86188p043438k03/>. Accessed: Oct. 02, 2012 . doi: 0.1023/A:1013901909797.

STROHECKER, R.; HENNING, H.M. Analisis de vitaminas: métodos comprobados. Madrid: Paz Montalvo, 1967. 428p.

ZHENG, H.; LU, H.F. Use of kinetic, Weibull and PLSR models to predict the retention of ascorbic acid, total phenols and antioxidant activity during storage of pasteurized pineapple juice. LWTFood Science and Technology, v.44, n.5, p.1273-1281, 2011. Available from: $<$ http://www.sciencedirect.com/science/article/pii/ S0023643810004470>. Accessed: Aug, 21, 2014. doi:10.1016/j. lwt.2010.12.023.

TAIZ, L.; ZEIGER, E. Fisiologia vegetal. 5.ed. Porto Alegre: ArtMed, 2013. 954p. 